\title{
Analysis on Tax Planning of Comprehensive Income Under the New Tax Law
}

\author{
Qing Xu \\ School of Accounting \\ Fujian Jiangxia University \\ Fuzhou, China 350108
}

\begin{abstract}
China's new tax law was passed on August 31, 2018, and will take effect on January 1, 2019. The new tax law will make small and comprehensive taxation on wages, salary income, labor remuneration income, remuneration income and royalties, and realize the transformation of China's individual tax system from the classification tax system to the comprehensive and classified tax system, a landmark reform of the comprehensive tax system. In this context, it is particularly important to comprehensively analyze the relevant tax-related provisions of comprehensive income and propose corresponding planning ideas.
\end{abstract}

Keywords-new tax method; comprehensive income; planning ideas

\section{INTRODUCTION}

Looking at the whole world, there are three tax system models for individual income tax, namely, comprehensive tax system, classified tax system and comprehensive and classified tax system. The United States is implementing a large comprehensive tax. The greater the comprehensive income range, the fairer, and the higher the requirements for the collection and management. China's "Personal Income Tax Law of the People's Republic of China" (hereinafter referred to as the new tax law) (No. 9 of the Presidential Decree of the People's Republic of China) [1] was adopted at the fifth meeting of the Standing Committee of the 13th National People's Congress on August 31, 2018. It will take effect on January 1, 2019. Article 2 of the new tax law stipulates that 9 personal incomes shall be subject to personal income tax, that is, income from wages and salaries; income from labor remuneration; income from remuneration; income from royalties; income from operations; income from interest, dividends, dividends; Income from the transfer of property; accidental income. The first four items are called comprehensive income, and the individual residents calculate the individual tax according to the tax year. Non-resident individuals calculate the personal income tax on a monthly or sub-item basis. It can be seen that China's tax reform is a combination of a tax system from a classified tax system to a comprehensive tax system, and a small comprehensive tax is implemented. As the conditions are ripe, the scope of the collection of comprehensive income tax in China will continue to expand, and its ultimate goal will be to move toward a large comprehensive tax system [2]. This paper intends to comprehensively analyze the relevant tax-related provisions of comprehensive income from nine aspects and propose corresponding planning ideas.

\section{TAX INCENTIVES FOR SHORT-TERM NON-RESIDENT INDIVIDUALS}

\section{A. Tax Planning Ideas}

Article 1 of the new tax law stipulates that an individual who has no residence in China and does not live or has no domicile and who has lived in China for less than 183 days in a tax year is a non-resident individual. Non-resident individuals' income from China shall be subject to personal income tax in accordance with the new tax law. The income of wages and salaries of non-resident individuals shall be the taxable income after deducting the monthly income of 5,000 Yuan; the income from labor remuneration, the income from remuneration, and the royalties shall be the taxable income per income. The balance of income from labor remuneration, remuneration, and royalties is $20 \%$ of the income, and the balance is the amount of income. The amount of income from the remuneration is calculated at $70 \%$. Non-residen individuals apply the non-resident personal income tax rate table to calculate the personal income tax payable.

Article 5 of the new Tax Law Implementation Regulations stipulates that an individual who does not have a domicile in China who has lived in China for a total of no more than 90 days in a tax year shall be paid by the foreign employer and not by the employer. Part of the burden on institutions and places in China is exempt from personal income tax

Then, if the tax burden of non-resident individuals abroad is relatively light, if the conditions permit, the accumulated days of residence in China can be controlled within 90 days, thereby enjoying the benefits of domestic income exemption from taxation within China.

\section{B. Planning Case Analysis}

Ms. $\mathrm{Xu}$ is a permanent resident of Hong Kong, China, working for Hong Kong Company A. In 2019, Company A plans to arrange for Ms. Xu to work in the representative office in Shenzhen for 180 days (6 months). Ms. Xu's monthly salary for 2019 is 25,000 Yuan, and the total salary for 6 months is 1,500 million Yuan. If she is taxed in Hong 
Kong, she can enjoy more deductions and the tax burden is close to zero.

If not planned, Ms. Xu's six-month salary from China must be taxed in China. The monthly personal income tax $=$ $(25,000-5,000) \times 20 \%-1,410=2590$ (Yuan); 6 months total personal income tax $=2,590 \times 6=15,540$ (Yuan).

If planning, Company A can send two employees to work in Shenzhen, each working 90 days; the monthly salary is 25,000 Yuan. Therefore, the tax benefits of short-term nonresident individuals can be enjoyed, that is, the wages obtained by the two employees during their work in Shenzhen can be taxed in Hong Kong (the actual tax burden is close to 0 ), and there is no need to pay personal income tax in Shenzhen. As a result, a total of 15,540 Yuan can be taxed for the two employees.

\section{TAX INCENTIVES FOR SHORT-TERM RESIDENTS}

\section{A. Tax Planning Ideas}

Article 4 of the new Tax Law Implementation Regulations stipulates that if an individual who has no domicile in China has lived in China for a total of 183 days of continuous annual dissatisfaction for 6 years; it shall be filed with the competent tax authority and originated from outside China and by an overseas unit or individual. The income paid is exempt from personal income tax. In one of the years in which China has accumulated 183 days of residence, it has been retired for more than 30 days, and its annual continuous life of 183 days in China has been reestablished.

Then, for those who come to China for a short period of time, if they stay longer than 183 days per year, they should make full use of the above-mentioned tax incentives for short-term residents. In the sixth year, they can maintain the identity of short-term residents for a period of 31 days.

\section{B. Planning Case Analysis}

$\mathrm{Ms} . \mathrm{Xu}$ is a permanent resident of Hong Kong, China. She founded Company A in Shenzhen and spends about 360 days a year in China. Since 2019, its annual taxable income is about 1,000,000 Yuan, and the annual rental income is 1,200 000 Yuan.

Without planning, since 2019, Ms. Xu's income from overseas rents can be tax-free for five years. Since the 6th year, Ms. Xu's rental income from overseas needs to pay personal income tax in China, and the monthly personal income tax $=100000 \times(1-20 \%) \times 20 \%=16000$ (Yuan); Personal income tax $=16000 \times 12=192,000$ (Yuan). If Ms. $\mathrm{Xu}$ has already paid personal income tax on the rental income of 1,200,000 Yuan overseas, she can deduct it from the above-mentioned taxable amount of 192,000 Yuan. Assuming that Ms. Xu actually pays 100,000 Yuan overseas, Ms. Xu should also pay a tax of 92,000 Yuan in China.

If Ms. Xu leaves the country for 31 days in each of the 6th years from 2019, Ms. Xu can maintain the identity of a short-term resident forever. The annual rental income of
1,200,000 Yuan from overseas can be exempted from taxation in China. You can save 92,000 Yuan a year.

\section{Planning For the AVERAge Wage Payment of NON-RESIDENT INDIVIDUALS}

\section{A. Tax Planning Ideas}

Article 2 of the new tax law stipulates that non-resident individuals may obtain personal income tax on a monthly or sub-item basis for obtaining income from wages, salaries, labor remuneration, remuneration income, and royalties. The wages and salary income are subject to an excessive progressive tax rate. If the monthly salary is too high, a higher tax rate will be applied, thereby increasing the tax burden. Only the average wage is paid to achieve the lowest tax burden.

\section{B. Planning Case Analysis}

$\mathrm{Ms} . \mathrm{Xu}$ is a foreign national and belongs to a nonresident individual in China. Due to work needs, I stay in China for 4 months each year and receive 4 months of salary. The company originally planned to pay wages based on job performance, assuming that the four-month salary received in 2019 was 3,000 Yuan, 8,000 Yuan, 13,000 Yuan and 26,000 Yuan, respectively, totaling 50,000 Yuan. Ms. Xu's personal income tax in China in $2019=(8$ 000-5 $000) \times 3 \%+(13000-5000) \times 10 \%-210+(26000-5000) \times 20 \%-1$ $410=3470$ (Yuan).

If $\mathrm{Ms}$. Xu pre-estimates that the total salary for four months is 50,000 Yuan, it can be issued on an average basis. That is, the monthly salary is paid at 12,500 Yuan. Ms. Xu's personal income tax in China in 2019 is [(12 500$5000) \times 10 \%-210] \times 4=2160$ (Yuan). Savings tax = 3 470-2 $160=1310$ (Yuan).

\section{Planning FOR Special AdDitional Deductions}

\section{A. Planning for Special Deductions for Children's Education}

1) Tax planning ideas

According to the tax law, the taxpayer's children's expenditures for full-time academic education are deducted according to the standard of 1,000 Yuan per child per month. Academic education includes compulsory education (primary and junior high school education), high school education (ordinary high school, secondary vocational, technical education), higher education (university, university, master, doctoral education). Children who are at least 3 years old and are in pre-school education before entering primary school are required to do so. Parents may choose to deduct $100 \%$ of the deduction standard by one of them, or they may choose to deduct $50 \%$ of the deduction standard by the two parties. The specific deduction method cannot be changed within one tax year.

Then, when there are children between the ages of 3 and 28 who are educated in the family, they should actively declare. If both husband and wife are required to pay personal income tax, the child education deduction should be 
fully reported by the party with the higher tax rate, and the party with the lower tax rate will not declare it.

\section{2) Planning case analysis}

Mr. Xu and Mrs. Xu have one son and one daughter. The son is in the third grade of elementary school and the daughter is in the first grade of junior high school. In 2019, Mr. Xu's annual taxable income was 80,000 Yuan (not considering the special deduction of children's education), and Mrs. Xu's annual taxable income was 30,000 Yuan (not considering the special deduction of children's education).

If $\mathrm{Mr} . \mathrm{Xu}$ and Mrs. Xu have forgotten to declare special supplementary deductions for their children's education, in 2019, Mr. Xu should be subject to personal income tax = $80,000 \times 10 \%-2,520=5,480$ (Yuan); Mrs. Xu should be subject to personal income tax $=30,000 \times 3 \%=900$ (Yuan).

If Mrs. $\mathrm{Xu}$ declares that the special education for two children is deducted by $24000 \mathrm{Yuan}$, then in 2019, Mr. Xu should be subject to personal income tax $=80000 \times 10 \%$ $2520=5480$ (Yuan); Mrs. Xu should be subject to personal income tax $=(30,000-24,000) \times 3 \%=180$ (Yuan). Savings $\operatorname{tax}=900-180=720$ (Yuan)

If $\mathrm{Mr}$. $\mathrm{Xu}$ and $\mathrm{Mrs}$. $\mathrm{Xu}$ declare a special education deduction of 12,000 Yuan for a child, then in 2019, Mr. Xu should be subject to personal income tax $=(80000-12000)$ $\times 10 \%-2520=4280$ (Yuan); Mrs. Xu should be subject to personal income tax $=(30,000-12,000) \times 3 \%=540$ (Yuan). Savings tax $=5,480-4,280+900-540=1,560$ (Yuan).

If $\mathrm{Mr}$. $\mathrm{Xu}$ declares that the special education for two children is deducted by 24,000 Yuan, then in 2019, Mr. Xu should be subject to personal income tax $=(80,000-24,000)$ $\times 10 \%-2,520=3,080$ (Yuan); Mrs. Xu should Personal income $\operatorname{tax}=30,000 \times 3 \%=900$ (Yuan). Savings tax $=5$ $480-3080=2,400$ (Yuan).

For Mr. Xu and his wife, the maximum amount of the special supplementary tax deduction for the education of 24,000 Yuan is 2,400 Yuan.

\section{B. Planning for Additional Deductions for Major Medical Care}

\section{1) Tax planning ideas}

According to the tax law, in a tax year, the taxpayer's medical expenses related to basic medical insurance, after deducting the personal burden of medical insurance reimbursement (referring to the self-pay part of the medical insurance catalogue), exceeds the total of 15000 Yuan, by the taxpayer. In the case of annual settlement and settlement, it is deducted within the limit of 80,000 Yuan. The medical expenses incurred by the taxpayer may be deducted by the person or his or her spouse; the medical expenses incurred by the minor child may be deducted by the parent. The medical expenses incurred by taxpayers, their spouses and minor children shall be calculated separately according to the above provisions.

Then, when a taxpayer has a medical fee that meets the above requirements, it should actively declare the deduction. Medical expenses that meet the above requirements for a taxpayer's minor child shall be deducted from the parent who has the highest tax rate.

\section{2) Planning case analysis}

$\mathrm{Mr}$. Xu and Mrs. Xu liked to add a lot of money in 2019, but because her daughter had congenital diseases, she spent 100,000 Yuan in medical expenses, and she was all conceited. Mr. Xu and Mrs. Xu did not have self-financing medical expenses. In 2019, Mr. Xu's taxable income was 200,000 Yuan (not considering the special deduction for major medical care), and Mrs. Xu's taxable income was 80,000 Yuan (not considering the special deduction for major medical care).

If $\mathrm{Mr}$. Xu and Mrs. Xu have forgotten to file a special deduction for major medical treatment due to negligence, then in 2019, Mr. Xu should be subject to personal income $\operatorname{tax}=200000 \times 20 \%-16920=23080$ (Yuan); Mrs. Xu should be subject to personal income tax $=80000 \times 10 \%-2$ $520=5480$ (Yuan)

If Mrs. Xu declares a special medical deduction of 80,000 Yuan, then in 2019, Mr. Xu should be subject to personal income tax $=200000 \times 20 \%-16920=23080$ (Yuan); Mrs. Xu should pay a personal income tax of 0 Yuan. The tax is 5480 Yuan.

If $\mathrm{Mr}$. Xu declares a special deduction of 80,000 Yuan for major medical care, in 2019, Mr. Xu should be subject to personal income tax $=(200000-80000) \times 10 \%-2520=9$ 480 (Yuan); Mrs. Xu should be subject to personal income $\operatorname{tax}=80000 \times 10 \%-2520=5480$ (Yuan). Savings tax $=$ $23080-9480=13600$ (Yuan).

For $\mathrm{Mr} . \mathrm{Xu}$ and his wife, the maximum amount of deductible tax deduction for the 80,000 Yuan major medical treatment is 13600 Yuan.

\section{Planning for the Special Additional Deduction of the Elderly}

1) Tax planning ideas

According to the tax law, the taxpayer's maintenance expenses for one or more dependents are uniformly deducted according to the following criteria: (1) If the taxpayer is the only child, it is deducted according to the standard of 2,000 Yuan per month; (2) the taxpayer is For those who are not only children, they shall share the monthly deduction of 2,000 Yuan with their brothers and sisters. The amount of each person's contribution shall not exceed 1,000 Yuan per month. It can be shared by the supporters or agreed to be shared, or it can be allocated by the dependents. A written agreement shall be signed for the appointment or its designation, and the apportionment shall take precedence over the agreed apportionment. The specific allocation method and amount cannot be changed within one tax year. A dependent person is a parent who is 60 years of age or older, and a grandparent or grandparent who has passed away at the age of 60 .

Then, all taxpayers who are dependent on the 60-year-old should actively apply for special deductions for the support 
of the elderly. For many brothers and sisters, the highest tax rate should be declared separately for 1,000 Yuan.

\section{2) Planning case analysis}

$\mathrm{Mr}$. Xu and his wife are both 60 years old and their three children are Xu Da, Xu Er and Xu San. In 2019, Xu Da's taxable income was 80,000 Yuan, Xu Er's taxable income was 30,000 Yuan, and Xu San's taxable income was 0. The above amount did not consider the special additional deduction for the support of the elderly.

If the three children are negligently undeclared for the special deduction of the elderly, then in 2019, Xu Daying personal income tax $=80000 \times 10 \%-2520=5480$ (Yuan); $\mathrm{Xu}$ Er should personal income tax $=30000 \times 3 \%=900$ (Yuan); Xu San should pay a personal income tax of 0 Yuan.

If $\mathrm{Xu}$ Eryi declares a special deduction of 12000 Yuan for the elderly, then in 2019, Xu Daying personal income tax $=80000 \times 10 \%-2520=5480$ (Yuan); Xu Er should be subject to personal income tax $=(30000-12000) \times 3 \%=$ 540 (Yuan); Qin San should be subject to personal income tax of 0 Yuan.

If Xu Dayi declares a special deduction of 12000 Yuan for the elderly, then in 2019, Xu Daying personal income tax $=(80000-12000) \times 10 \%-2520=4280$ (Yuan); Xu Er should be subject to personal income tax $=30000 \times 3 \%=$ 900 (Yuan); Xu San should be subject to personal income tax of 0 Yuan. Savings tax $=5$ 480-4 280 = 1200 (Yuan).

If $\mathrm{Xu} \mathrm{Da}$ and $\mathrm{Xu}$ Er declare a special deduction of 12000 Yuan for the elderly, then in 2019, Xu Da Ying personal income tax $=(80000-12000) \times 10 \%-2520=4280$ (Yuan); $\mathrm{Xu}$ Erying Personal income tax $=(30000-1200) \times 3 \%=540$ (Yuan); Xu San should be subject to personal income tax of 0 Yuan. Savings tax $=5480-4280+900-540=1560$ (Yuan).

For the three brothers and sisters of Xu Family, the maximum amount of the special deductible tax deduction for the 24,000 Yuan of the elderly is 1560 Yuan.

\section{YEAR-END AWARD PLANNING FOR SEPARATE TAXATION}

\section{A. Tax Planning Ideas}

Individual residents who have obtained one-time bonus for the whole year are in compliance with the "Notice of the State Administration of Taxation on Adjusting Individuals to Acquire Individual Income Taxes for One-Year One-Year Bonus" (Guo Shui Fa [2005] No. 19), in December 2021. Before 31st, it may not be incorporated into the comprehensive income of the current year. The annual onetime bonus income divided by the amount obtained in 12 months shall be determined according to the monthly comprehensive income tax rate table (hereinafter referred to as the monthly tax rate table) attached to this notice. According to the calculation, the "invalid interval" for the bonus is divided into six sections, namely: 360001-38566.67 Yuan; 144001-160500 Yuan; 300001-318333.33 Yuan; 420001-447500 Yuan; 660001-706538.46 Yuan; 9600011120000 Yuan. Enterprises and related units should try to avoid setting the pre-tax year-end bonus in the "invalid period" when issuing the year-end awards [3].

The year-end award is taxed separately. It provides an additional method for taxpayers to pay tax at a lower rate. Taxpayers with a comprehensive tax payable of more than 36000 Yuan should make full use of it. The use of year-end bonuses for tax planning should pay attention to two issues: First, the tax rate applicable to the year-end award cannot exceed the maximum tax rate applicable to the comprehensive income. Otherwise, the effect of saving taxes cannot be achieved. Second is the calculation method of the year-end award. In fact, it is full progressive [4]. Therefore, special attention should be paid to the tax planning in the transition phase of the two tax rates. In principle, if the applicable tax rate of a year-end award just exceeds a certain grade, the amount of the year-end bonus is appropriately reduced. Its application of a lower grade tax rate can have a tax-saving effect.

\section{B. Planning Case Analysis}

Mr. Xu's 2019 comprehensive income taxable income is 1,000,000 Yuan, all from wages and salaries. The unit has provided five options for its choice: Option 1, all through wages and salaries, not to issue year-end awards; Option 2, to issue 36000 year-end awards, comprehensive income taxable income of 964000 Yuan; Option 3, issuance The 144 000 Yuan year-end award, the comprehensive income taxable income is 856,000 Yuan; the program 4, the 430,000 year-end award, the comprehensive income taxable income is 570,000 Yuan; the scheme 5, the 420,000 Yuan year-end award, the comprehensive income should be The taxable income is 580,000 Yuan.

Under Option 1, Mr. Xu should pay tax $=1000000 \times$ $45 \%-181900=268100$ (Yuan)

Under Option 2, Mr. Xu's comprehensive income tax payable $=964000 \times 45 \%-181900=251900$ (Yuan); yearend bonus payable $=36000 \times 3 \%=1100$ (Yuan); total tax payable $=251900+1100=253000$ (Yuan). Option 2 is taxed by option $1=268100-253000=15100$ (Yuan).

Under Option 3, Mr. Xu's comprehensive income tax payable $=856000 \times 35 \%-85900=213700$ (Yuan); yearend bonus payable $=144000 \times 10 \%-200=14200$ (Yuan); Tax payment $=213700+14200=227900$ (Yuan). Option 3 is tax-efficient compared to option $2=253,000-227900=$ 25100 (Yuan); programme 3 is taxed by programme $1=268$ $100-227900=40200$ (Yuan).

Under Option 4, Mr. Xu's comprehensive income tax payable $=570000 \times 30 \%-52900=18100$ (Yuan); yearend bonus payable $=430000 \times 30 \%-4400=124600$ (Yuan); Tax payable $=18100+124600=242700$ (Yuan). Option 4 is more taxable than option $3=242700-227900=$ 14800 (Yuan); programme 4 is less than programme 2 tax $=$ $253,000-242700=10300$ (Yuan); programme 4 is less than scheme 1 tax $=268100-242700=25400$ (Yuan).

Under Option 5, Mr. Xu's comprehensive income tax payable $=580000 \times 30 \%-52900=121100$ (Yuan); year end bonus payable $=420000 \times 25 \%-2700=102300$ 
(Yuan); Tax payable $=121100+102300=223400$ (Yuan). Programme 5 is tax-efficient to programme $4=242700-223$ $400=19300$ (Yuan); programme 5 is tax-efficient on programme $3=227900-223400=4,500$ (Yuan); programme 5 is more cost-effective than programme $2=$ $253,000-223400=29600$ (Yuan); programme 5 is taxed by programme $1=268100-223400=44700$ (Yuan).

\section{PlanNING IN THE PAYMENT OF LABOR COMPENSATION}

\section{A. Tax Planning Ideas}

Although the income from labor remuneration should be incorporated into the comprehensive income, the individual income tax is collected. However, in the actual collection and management, the combination of prepayment and settlement and payment is adopted. When the withholding agent pays the income of the labor remuneration to the resident individual, the prepaid tax shall be withheld on a monthly or monthly basis according to the following methods: (1) the balance of the income from labor remuneration after deducting the income is the amount of income; (2) when the withholding tax is withheld, the income from the remuneration for labor services shall not exceed 4,000 Yuan, and the deduction shall be calculated at 800 Yuan; for each income of more than 4,000 Yuan, the deduction shall be calculated at $20 \%$ of the income; The income from labor remuneration shall be the withholding taxable amount of each with the amount of income prepaid, and the withholding tax shall be withdrawn. The income from labor remuneration shall be subject to the personal income tax withholding rate table; (4) when the individual handles the annual comprehensive income settlement, the income of the labor remuneration shall be calculated according to law, and the annual comprehensive income shall be included in the calculation of the tax payable, and the tax shall be refunded.

Then, according to the above-mentioned withholding method, the taxpayer should try to reduce the amount of labor remuneration for each time, so that the amount of withholding tax withheld can be reduced.

\section{B. Planning Case Analysis}

$\mathrm{Ms} . \mathrm{Xu}$ is a professor at a university. In 2019, she worked as a tax consultant for Company A. The contract stipulated two payment schemes: Option 1, Company A paid the annual consultant fee of 60,000 Yuan to Ms. Xu in 2019; Option 2, Company A In 2019, she paid Ms. Xu 12 years of consulting fees for the whole year, 5,000 Yuan each time. Assume that Ms. Xu's 2019 comprehensive income taxable income (including the 60,000 Yuan consultant fee) is 100,000 Yuan. Except for the consultant fee, no tax has been paid in advance.

Under Option 1, Company A shall withhold the advance tax when paying the consultant fee $=60000 \times(1-20 \%) \times$ $30 \%-2000=12400$ (Yuan). Ms. Xu's 2019 comprehensive income tax payable $=100000 \times 10 \%-2520$
$=7480$ (Yuan). Mr. Xu should apply for tax refund $=12$ 400-7 $480=4920$ (Yuan).

Under Option 2, Company A shall withhold the advance tax when paying the consultant fee $=5000 \times(1-20 \%) \times 20 \%$ $\times 12=9600$ (Yuan). Ms. Xu's 2019 comprehensive income tax payable $=100000 \times 10 \%-2520=7480$ (Yuan). Ms. $\mathrm{Xu}$ should apply for tax refund $=9600-7480=2120$ (Yuan). Option 2 takes less than Ms. Xu's funds $=4$ 920$2120=2800$ (Yuan).

\section{TRANSFORMING THE REMUNERATION OF LABOR SERVICES INTO THE PLANNING OF THE COMPANY'S OPERATING INCOME}

\section{A. Tax Planning Ideas}

From January 1, 2019 to December 31, 2021, VAT small-scale taxpayers with monthly sales of less than 100,000 Yuan (including this number) are exempt from VAT. For the small-profit enterprise with an annual taxable income of not more than 1 million Yuan, the amount of taxable income shall be reduced by $25 \%$, and the enterprise income tax shall be paid at the rate of $20 \%$; the annual taxable income shall exceed 1 million Yuan but not exceeding The portion of 3 million Yuan shall be deducted from the taxable income by $50 \%$, and the enterprise income tax shall be paid at the rate of $20 \%$.

Then, for individuals who frequently receive labor remuneration and have a large amount, they may consider setting up a company to provide relevant labor services, thereby converting the income of personal labor compensation into company income. Since small and micro enterprises can enjoy more tax incentives, this change can greatly reduce the individual's tax burden.

\section{B. Planning Case Analysis}

$\mathrm{Ms} . \mathrm{Xu}$ is a professor at a university whose income is mainly the salary of the university and the remuneration for lectures at a training institution. In 2019, the total amount of wages paid by the university is 200,000 Yuan, regardless of other income, and the calculated comprehensive income taxable income is 36,000 Yuan. The training institution pays Ms. Xu a monthly remuneration of 80,000 Yuan. If we consider the remuneration, Ms. Xu's comprehensive income taxable income for 2019 will be raised to 804,000. The tax planning company provided $\mathrm{Ms}$. $\mathrm{Xu}$ with two sets of programs: Option 1, continuing the previous model, and the training institution paid $\mathrm{Ms}$. $\mathrm{Xu}$ a monthly remuneration of 80,000 Yuan; in Scenario 2, Ms. Xu established Company A to issue 80000 monthly training institutions. Invoice for the Yuan training fee, company A obtained 80,000 Yuan in income.

Under Option 1, Ms. Xu's comprehensive income tax payable $=804,000 \times 35 \%-85900=195500$ (Yuan)

Under Option 2, Ms. Xu's comprehensive income tax payable $=36000 \times 3 \%=1080$ (Yuan); Company $\mathrm{A}$ receives a training fee of 80,000 Yuan per month, according to the small and micro enterprise VAT preferential policy, no 
need to pay VAT and its addition, according to the microenterprise income tax preferential policy, Company A needs to pay corporate income tax $=80000 \times 12 \times 25 \% \times 20 \%=$ 48000 (Yuan), total tax $=1080+48000=49080$ (Yuan). Option 2 is less tax than Option $1=195500-49080=146$ 420 (Yuan).

\section{The TAX PlanNING OF THE REMUNERATION INCOME}

\section{A. Tax Planning Ideas}

When the withholding agent pays the income of the remuneration to the resident individual, the prepaid tax shall be withheld on a monthly or monthly basis according to the following methods: (1) The balance of the remuneration income after deducting the income is the amount of income; the income from the remuneration; (2) When the withholding tax is withheld, the income from the remuneration shall not exceed 4,000 Yuan, and the deduction shall be calculated at 800 Yuan; for each income of more than 4,000 Yuan, the fee shall be deducted. $20 \%$ of the income is calculated; (3) The income from the remuneration is based on the amount of the advance taxable income, and the withholding tax is calculated. The remuneration income shall be subject to a $20 \%$ ratio of withholding rate; (4) When the individual handles the annual comprehensive income settlement, the income of the remuneration shall be calculated according to law.

In addition to the salary and salary income and the method of planning the income from labor remuneration, the most important method is to divide the number of times and distribute it to multiple taxpayers, and reduce the amount of withholding tax, such as the taxpayer's annual comprehensive income. The amount has changed a lot and can be adjusted between different years.

\section{B. Planning Case Analysis}

Ms. Xu published a textbook in A Publishing House with a total remuneration of 80,000 Yuan. It is known that Ms. $\mathrm{Xu}$ 's 2019 comprehensive income taxable income is 36000 Yuan, and the 2020 comprehensive income taxable income is 0 Yuan. At the same time, there is a 40,000 Yuan fee to allow pre-tax deduction. Regarding the time for the payment of the pen, A publisher provided two programs: program 1, paying 80,000 Yuan at the end of 2019; program 2, paying 80,000 Yuan at the beginning of 2020.

Under option 1, the pen should pay personal income tax $=80000 \times 70 \% \times(1-20 \%) \times 10 \%=4480($ Yuan $)$.

Under Option 2, the pen should be subject to individual income tax $=[80000 \times 70 \% \times(1-20 \%)-40000] \times 3 \%=$ 144 (Yuan).

Option 2 is less tax than Option $1=5600-144=5456$ (Yuan)

\section{TAX PlanNing FOR Royalties}

\section{A. Tax Planning Ideas}

When the withholding agent pays the income of the royalties to the resident individual, the prepaid tax shall be withheld or paid in accordance with the following methods: (1) the income from the royalties shall be the income after deducting the expenses; (2) when the withholding tax is withheld, the income from the royalties shall not exceed RMB 4, and the deduction shall be calculated at 800 Yuan (3) income from royalties, with the amount of taxable income prepaid for each withholding amount, as well as the withholding tax, shall be withdrawn. The royalty income shall be subject to a $20 \%$ ratio withholding rate; (4) when the individual handles the annual comprehensive income settlement, the income from the royalties shall be calculated according to law, and the annual comprehensive income shall be included in the calculation of the tax payable. Taxes are refunded more and less.

In addition to the flexible use of the above-mentioned wage and salary income, labor remuneration income, and remuneration income planning methods, the most important thing is to choose to pay the royalties on an annual basis instead of paying for two or more years.

\section{B. Planning Case Analysis}

$\mathrm{Ms} . \mathrm{Xu}$ is an engineer of Company A. The annual taxable income of the company is 36000 Yuan. In 2019, Ms. Xu obtained a patent and granted it to Company B for 10 years, with a total patent fee of 1,000,000 Yuan. Regarding the payment method of patent fees, Company B has designed 3 sets of plans: Option 1: Pay a patent fee of 500,000 Yuan every 5 years, and pay 2 times; Plan 2, pay a patent fee of 200,000 Yuan every 2 years, and pay 5 times; Option 3 , paying a patent fee of 100,000 Yuan per year for a total of 10 times.

Under Option 1, Ms. Xu obtained a personal income tax of 500,000 Yuan for patent fees $=(14.4-3.6) \times 10 \%+(30$ $14.4) \times 20 \%+(42-30) \times 25 \%+(53.6-42) \times 30 \%=10.68($ ten thousand Yuan); total personal income tax $=10.68 \times 2=$ 21.36 (ten thousand Yuan)

Under Option 2, Ms. Xu obtained a personal income tax of 200,000 Yuan for patent fees $=(14.4-3.6) \times 10 \%+(23.6$ $14.4) \times 20 \%=2.92$ (ten thousand Yuan); total personal income tax $=2.92 \times 5=14.6$ (ten thousand Yuan). Option 2 is less tax than Option $1=21.36-14.6=6.76$ (million).

Under Option 3, Ms. Xu obtained a personal income tax of 100,000 Yuan for patent fees $=10 \times 10 \%=1$ (ten thousand Yuan); total personal income tax $=1 \times 10=10$ (ten thousand Yuan). Option 3 is less than the plan 2 tax $=14.6$ $10=4.6$ (ten thousand Yuan). Option 3 is less tax than Option $1=21.36-10=11.36$ (ten thousand Yuan).

\section{CONCLUSION}

Generally speaking, the government is more willing to introduce tax reduction policies for enterprises, and there are few tax reduction policies for individuals. Because of the 
lack of policy flexibility, the space for personal income tax planning is extremely limited compared to corporate income tax. In particular, after the revision of the tax law, the labor income will be taxed on an annual basis, and the room for adjustment of the individual tax is even smaller. However, the individual income tax can still be planned from the above nine aspects.

\section{ACKNOWLEDGMENT}

This paper belongs to the project of the Fund Project "Fund Project Type: 'Fujian Jiangxia College Horizontal Project'; Fund project number: JXH2019001; Fund Project Name: Research on Enterprise Financial Specification Reorganization Based on Tax Auditing Perspective".

\section{REFERENCES}

[1] Individual Income Tax Law of the People's Republic of China (2018 Amendment) [EB/OL]. http://www.fjtax.com.cn/ Fujian Tax Advisory Network, 2018-8-31/2018-10-09.

[2] Xu Qing, Yuan Ling. Analysis of the Change of Entity Content and Planning Thoughts of the New Individual Income Tax Law [J]. Journal of Jilin Business School, 2018(6):74-78.

[3] Qi Jiguang. The classic case study of reasonable tax and tax avoidance in enterprises [M]. Shanghai: Lixin Accounting Publishing House, 2019. 